\title{
STRATEGI MANAJEMEN KEPALA MADRASAH DALAM MENGEMBANGKAN SUMBER DAYA GURU DI MTS PERSIAPAN NEGERI HADUNDUNG KECAMATAN KOTA PINANG KABUPATEN LABUHANBATU SELATAN
}

\author{
Candra Wijaya \\ Email: candrawijaya@,uinsu.ac.id \\ Pascasarjana UIN Sumatera Utara \\ Achyar Zein \\ Email: achyar.zein@yahoo.com \\ Pascasarjana UIN Sumatera Utara \\ Ali Ahmad Rapi Tanjung \\ Email: aliahmadrapi01@qmail.com \\ Mahasiswa Program Studi Pendidikan Islam \\ Pascasarjana UIN Sumatera Utara
}

\begin{abstract}
Abstrak: Penelitian ini bertujuan untuk menganalisis: 1) Strategi perencanaan kepala madrasah dalam mengembangkan sumber daya guru di MTs Persiapan Negeri Hadundung Kecamatan Kota Pinang Kab. Labuhanbatu Selatan. 2) Strategi pelaksanaan kepala madrasah dalam mengembangkan sumber daya guru di MTs Persiapan Negeri Hadundung Kecamatan Kota Pinang Kab. Labuhanbatu Selatan. 3) Strategi pengawasan kepala madrasah dalam mengembangkan sumber daya guru di MTs Persiapan Negeri Hadundung Kecamatan Kota Pinang Kab. Labuhanbatu Selatan. Penelitian menggunakan pendekatan kualitatif naturalistik. Teknik pengumpulan data penelitian berupa observasi, wawancara dan dokumentasi. Hasil penelitian ini mengungkapkan Tiga temuan yaitu: Hasil temuan peneltian adalah: 1) Strategi perencanaan kepala madrasah dalam mengembangkan sumberdaya guru di MTs Persiapan Negeri Hadundung Kecamatan Kota Pinang Kab. Labuhanbatu Selatan seperti untuk mengadakan program pelatihan untuk mengembangkan sumber daya guru untuk mewujudkan kualitas kerja guru yang profesional. 2) Strategi pelaksanaan kepala madsarasah dalam mengembangkan sumber daya guru bawasannya kepala sekolah melakukan rapat MGMP (Musyawarah Guru Mata Pelajaran) kepada seluruh guru yang ada di madrasah tersebut. Kemudian kepala sekolah mengirimkan beberapa guru-guru dalam setiap tiga bulan sekali mengikuti pelatihan, pembina seperti worshop,diklat serta pembuatan RPP, silabus dan kurikulum 2013. Untuk mengembangkan dan
\end{abstract}


Edu Riligia : Vol. 4 No. 1 Januari- Maret 2020

pembinaan para guru-guru tersebut. 3) Strategi pengawasan kepala madrasah dalam mengembangkan sumber daya guru di MTs Persiapan Negeri Hadundung Kecamatan Kota Pinang Kab. Labuhanbatu Selatan bahwasannya kepala sekolah dengan melakukan mengobservasi kelas dan melihat kondisi kelas dan kemudian kepala sekolah melakukan komunikasi dengan baik dengan para guru-guru dan kepala sekolah memberi pengembangan guru berupa pelatihan untuk kesejatraan guru.

Kata Kunci: Strategi, Manajemen, dan Guru

\section{Pendahuluan}

Upaya mewujudkan cita-cita pembangunan nasional sebagaimana tertuang dalam UUD 1945 ini salah satunya menempatkan sektor pendidikan pada posisi dan peran yang sangat strategis dalam akselerasi pembangunan. Peran itu secara prinsip mengarah pada adanya suatu tujuan yakni meningkatkan kemakmuran (prosperity) masyarakat secara keseluruhan disamping sebagai langkah untuk mewujudkan investasi sumber daya manusia (buman investment) yang penting di eraglobalisasi ini. Lebih lanjut secara khusus sasaran pembangunan di bidang pendidikan untuk semua jenis dan jenjang sekolah sebagaimana tercantum dalam Undang-Undang Sistem Pendidikan Nasional (UUSPN) Nomor 20 Tahun 2003 dimaksudkan sebagai upaya mencerdaskan kehidupan bangsa dan meningkatkan kualitas manusia Indonesia dalam mewujudkan masyarakat yang adil, dan makmur serta memungkinkan para warganya mengembangkan diri, baik berkenaan dengan aspek jasmaniah maupun rohaniah.

Sumber daya manusia merupakan aset yang sangat penting dalam suatu organisasi atau lembaga pendidikan dan mempunyai peranan yang sangat penting dalam mencapai tujuan yang telah di tetapkan di dalam suatu lembaga pendidikan. Sumber daya manusia tidak lain adalah ditentukan dari lulusan-lulusan lembaga pendidikan yang bermutu yang dapat menciptakan sumber daya manusia yang 
Candra Wijaya, dkk: Strategi Manajemen Kepala Madrasah

berkualitas dan berkepribadian unggul. Untuk sebab itulah maka manajemen atau pengelolaan pendidikan harus lebih diutamakan d alam segala hal.

Menurut Amiruddin mengenai manajemen merupakan upaya memperdayakan seluruh sumber daya yang ada, baik sumber daya manusia maupun sumber daya fasilitas, agar proses pendidikan dan pembelajaran berlangsung secara efektif dan efesien untuk mencapai tujuan pendidikan dan pengajaran secara keseluruhan. Oleh karena itu, proses dan prosedur pemanfaatan sumber daya manusia dan sumber daya fasilitas merupakan substansi studi manajemen/administrasi pendidikan tersebut. ${ }^{1}$

Untuk kemajuan suatu lembaga pendidikan, seorang kepala sekolah madrasah harus mempunyai strategi manajemen yang dikelola dengan baik, yakni strategi yang benar-benar matang dan khas yang ada di suatu lembaga pendidikan tersebut. Karena kepala madrasah merupakan seorang pemimpin yang diberi tugas dilembaga pendidikan untuk mengatur dan mengelola sumber daya yang ada di lembaga pendidikan untuk meningkatkan mutu pendidikan serta kualitas pendidikan secara efektif dan efesien. Sesuai dengan fungsi kepala madrasah sebagai manajer, administrasi, supervisor, leader, innovator dan motivator.

Selain itu kepala madrasah merupakan kompenen yang sangat penting dalam menentukan berhasil atau tidaknya penyelenggaraan pendidikan yaitu guru. Guru merupakan sebagai ujung tombak pendidikan yang langsung berada di garis depan yang langsung berhadapan dengan siswa dituntut memiliki kompetensi yang memadai guna menanamkan nilai-nilai dan pembelajaran berbagai ilmu pengetahuan, pengalaman, dan keterampilan yang relevan dengan kekinian dan masa depan dapat berlangsung.

Salah satu upaya pengembangkan sumber daya guru adalah dengan melakukan pelatihan dan pengembangan. Pelatihan dan pengembangan merupakan kegiatan yang bermaksud memperbaiki dan mengembangkan sikap, 
Edu Riligia : Vol. 4 No. 1 Januari- Maret 2020

perilaku, keterampilan dan pengetahuaan para guru sesuai dengan kenginan lembaga pendidikannya baik bagi guru untuk guru yang baru dan guru yang lama.

Agar efektif, pelatihan biasanya harus mencakup pengalaman belajar, aktivitas-aktivitas yang terencana, dan desain sebagai jawaban atas kebutuhankebutuhan yang berhasil diidentifikasikan. Secara ideal, pelatihan harus didesaian untuk mewujudkan tujuan-tujuan organisasi, yang ada waktu yang bersamaan juga untuk mewujudkan tujuan-tujuan dari para guru secara perorangan. Pelatihan untuk guru biasanya dilakukan oleh lembaga-lembaga diklat atau dinas pendidikan/depag yang ditunjuk untuk memberikan fasilitas kepada guru untuk melakukan kegiatan pelatihan tersebut.

\section{Kajian Literatur}

\section{A. Strategi Manajemen Kepala Madrasah}

\section{Pengertian Strategi}

Secara umum strategi yaitu suatu garis-garis besar atau haluan untuk tindak dalam mencapai sasaran yang telah ditentukkan. ${ }^{2}$ Menurut Glueck, strategi adalah satu kesatuan rencana yang komperehensif dan terpadu yang menghubungkan kekuatan strategi organaisasi dengan likungan yang dihadapinnya, untuk menjamin tujuan organisasi akan tercapai. ${ }^{3}$ Menurut Lashway dalam buku Syafaruddin dan Asrul strategi adalah pola perilaku yang dirancang untuk mencapai kerjasama dan para anggota dalam mencapai tujuan organisasi. ${ }^{4}$ Menurut Hax di dalam buku Yusuf Hadijaya strategi merupakan pola atau rencana yang mengitegrasikan tujuan-tujuan utama, kebijakan-kebijakan, dan tindakan yang berurutan dari sebuah organisasi menjadi sebuah kesatuan yang utuh. ${ }^{5}$ 
Candra Wijaya, dkk: Strategi Manajemen Kepala Madrasah

\section{Pengertian Manajemen}

Kata Manajemen berasal dari bahasa Perancis kuno menagement yang memiliki arti seni melaksanakan dan mengatur. Manajemen belum memiliki definisi yang mapan dan diterima secara universal. ${ }^{6}$ Mary Parker dalam Barret misalnya mendefinisikan manajemen sebagai seni menyelesaikan pekerjaan melalui orang lain. ${ }^{7}$ Griffin mendefenisikan manajemen sebagai sebuah proses perencanaan, pengorganisasian, pengkoordinasian, dan pengontrolan sumberdaya untuk mencapai sasaran (goal) secara efektif dan efisien. Efektif berarti bahwa tujuan dapat dicapai sesuai dengan perencanaan, sementara efisien berarti bahwa tugas yang ada dilaksanakan secara benar, teroganisir dan sesuai dengan jadwal. ${ }^{8}$

Aktivitas manajemen mencakup spektrum yang sangat luas, sebab dimulai dari bagaimana menentukan arah organisasi di masa depan, menciptakan kegiatan-kegiatan organisasi, mendorong terbinannya kerjasama antara sesama anggota organisasi, serta mengawasi kegiatan dalam mencapai tujuan. Dalam rangka mencapai tujuan organisasi secara efektif dan efisien itulah, manajemen harus difungsikan sepenuhnya pada setiap organisasi, baik organisasi, industri, perbankan, maupun pendidikan. Fungsi-fungsi manajemen tersebut, yaitu: perencanaan; pengorganisasian; dan pengawasan.

\section{Manajemen Kepala Madrasah}

Kata Manajemen sendiri berasal dari kata manage (bahasa latinnya: manus) yang berarti: memimpin, menangani, mengatur, atau membimbing. Manajemen berasal dari kata to mange yang berarti mengelola. Pengelolaan dilakukan melalui proses dan dikelola berdasarkan urutan dan fungsi-fungsi manajemen itu sendiri. Manajemen adalah melakukan pengelolaan sumberdaya yang dimiliki oleh sekolah/organisasi yang di antaranya adalah 
Edu Riligia : Vol. 4 No. 1 Januari- Maret 2020

manusia, uang, metode, mesin, dan pemasaran yang dilakukan dengan sistematis dalam suatu proses. ${ }^{9}$ Di bidang pendidikan, pemerintah dan kemiliteran orang memakai istilah administrasi, sedangkan di bidang industri dan perusahan dipakai istilah manajemen.

\section{B. Pendidikan dan Pelatihan}

Perbedaan kedua istilah itu pada intinya mengarahkan bahwa pelatihan dimaksudkan untuk membantu meningkatkan kemampuan pegawai melaksanakan tugas sekarang, sedangkan pendidikan lebih berorientasi pada peningkatan produkktivitas kerja pegawai di masa depan. Akan tetapi perbedaan itu tidak perlu ditonjolkan karena kedua pengertian itu umumnya digunakan bersama-sama.

Dari beberapa pengertian di atas, dapat disimpulkan bahwa pelakasanaan pendidikan dan pelatihan menitikberatkan pada : (1) Membantu pegawai dalam menambah pengetahuan dan ketrampilan, (2) Pengetahuan dan ketrampilan tersebut sangat erat hubungannya dengan pekerjaan sekarang ataupun masa yang akan dating, dan (3) Pelaksanaan pendidikan dan pelatihan haruslah direncanakan dan diorganisasikan untuk mendapatkan efektivitas dalam pelaksanaan pendidikan dan latihan itu sendiri.

\section{Penelitian yang Relevan}

Penelitian terdahulu yang dianggap relevan dengan penelitian ini diantaranya:

a) Marhalim Nasution, dalam penelitian ini yang berjudul "Implementasi Manajemen Kepala Madrasah Untuk Meningkatkan Motivasi Mengajar Guru Di Madrasah Aliyah Al Washliyah Gedung Johor Medan” (Fakultas Tarbiyah IAIN Sumatera Utara Medan, 2012) dan hasil penelitian ini menujukkan tentang, a). Proses rekrutmen guru yang dilakukan oleh kepala madrasah, b). Proses seleksi guru yang dilakukan oleh kepala madrasah, c). 
Candra Wijaya, dkk: Strategi Manajemen Kepala Madrasah

Pelaksanaan pengembangan kompetensi guru yang dilkakukan oleh kepala madrasah.

b) Fitri Annisa Harahap, dalam penelitian yang berjudul "Pengembangan Profesionalitas Guru Madrasah Ibtidaiyah Swasta (MIS) Taqwa Di Kecamatan Tanah Jawa Kabup aten Simalungun" (IAIN SU Fakultas Tarbiyah/Jurusan Manajemen Pendidikan Islam/Tahun 2011) dan hasil penelitian ini yang menunjukkan tentang, a) bentuk-bentuk pengembangan profesionalitas guru, b) hambatan-hambatan yang dihdapi dalam pengembangan profesionalitas guru, c) upaya-upaya yang dilakukan dalam meningkatan pengembangan profesionalitas guru.

\section{Metode Penelitian}

Penelitian ini menggunakan pendekatan kualitatif deskriptif. Pendekatan ini bermaksud memberikan gambaran atau deskripsi suatu peristiwa secara sistematik dan objektif dengan cara mengumpulkan, mengevaluasi, memverifikasi, serta mensintesiskan bukti-bukti untuk mendukung fakta guna memperoleh suatu kesimpulan.

Pendekatan ini dapat didefenisikan sebagai berikut: Penelitian yang dilakukan berusaha untuk memaparkan suatu keadaan, gejala individu atau kelompok tertentu secara analisis yang dalam mengolah dan menganalisis datanya tidak tertumpu pada penggunaan angka-angka statistik, kecuali sebagai alat bantu. ${ }^{10}$

\section{Hasil dan Pembahasan}

\section{A. Perkembangan kemampuan profesionalisme guru di MTs Persiapan} Negeri Hadundung Kecamatan Kota Pinang Kab. Labuhanbatu Selatan

Dari uraian data yang telah penulis analisis, maka peneliti menyatakan bahwa kemampuan bersosialisasi para guru MTs Persiapan Negeri Hadundung 
Edu Riligia : Vol. 4 No. 1 Januari- Maret 2020

Kecamatan Kota Pinang Kab. Labuhanbatu Selatan sudah cukup baik dan cukup mendukung untuk keberhasilan pencapaian indikator dari visi dan misi MTs Persiapan Negeri Hadundung Kecamatan Kota Pinang Kab. Labuhanbatu Selatan.

\section{B. Kebijakan Kepala Madrasah Pada Peningkatan Kemampuan} Profesionalisme Guru MTs Persiapan Negeri Hadundung Kecamatan Kota Pinang Kab. Labuhanbatu Selatan.

Kebijakan kepala sekolah adalah suatu ketentuan kepala sekolah yang berupa rangkaian dan asas yang menjadi garis besar dan dasar rencana dalam pelaksanaan suatu pekerjaan serta cara bertindak dalam usaha mencapai sasaran (garis haluan) di sekolah. Jadi, dalam hal ini kepala sekolah atau madrasah bertanggung jawab untuk memajukan sekolah/madrasah yang ia pimpin.

Keberadaan madrasah sebagai lembaga formal penyelenggara pendidikan memainkan peran strategis dalam keberhasilan sistem pendidikan nasional. Kepala sekolah sebagai manajer dan pemimpin adalah bertanggung jawab dalam menerjemahkan dan melaksanakan kebijakan pendidikan nasional yang ditetapkan pemerintah. Dan setiap kebijakan harus selalu berhubungan dengan kesejahteraan dan pencerdasan masyarakat.

Kebijakan kepala MTs Persiapan Negeri Hadundung Kecamatan Kota Pinang Kab. Labuhanbatu Selatan terhadap peningkatan kemampuan profesionalisme guru di MTs Persiapan Negeri Hadundung Kecamatan Kota Pinang Kab. Labuhanbatu Selatan dari segi makro yaitu guru-guru diwajibkan membuat program tahunan, program semester, silabus dan RPP.

Agar kebijakan yang ditetapkan kepala madrasah berjalan sesuai dengan yang diharapkan, beliau memberikan motivasi kepada guru. Adapun 
Candra Wijaya, dkk: Strategi Manajemen Kepala Madrasah

motivasi yang dilakukan kepala madrasah yaitu: yaitu memberikan motivasimotivasi kepada guru itu bahwa setiap yang kita berikan kepada siswa akan kembali kepada kita (guru) artinya bahwa apa yang kita berikan kepada siswa itu tidak akan mereka lupakan, dan suatu saat pasti akan kita rasakan, apalagi kalau ikhlas dalam mengajar ini dapat dipastikan akan menjadi amal yang terus menerus akan diterima walaupun sudah meninggal dunia, mengikut sertakan guru-guru yang memiliki potensi untuk mengikuti lomba MTQ KORPRI Tingkat Nasional, MTQ antar Ponpes se-Indonesia, MTQ Internasional, mengumumkan guru yang berprest asi di depan siswa dan guru lalu misalnya setiap hari guru memberikan reword/hadiah kepada guru yang terbaik sebagai motivasi kedepannya untuk meningkatkan lagi kompetensinya dan kemampuannya di bidang itu.

\section{Efektifitas Kebijakan Kepala Madrasah MTs Persiapan Negeri Hadundung Kecamatan Kota Pinang Kab. Labuhanbatu Selatan}

Keberhasilan kepala madrasah ditandai dengan tampaknya mutu dari madarasah yang ia pimpin. Itu semua tidak terlepas dari peran kepala madrasah untuk mencari hal-hal yang perlu diperbaiki di madrasah, mencari solusi/kebijakan demi tercapainya pendidikan atau sekolah yang bermutu.

Berkenaan dengan keefektifan kebijakan kepala madrasah menurut peneliti sudah dapat dikatakan berhasil namun masih perlu di tingkatkan lagi kedepannya. Hal ini sesuai dengan pengamatan peneliti waktu di lapangan bahwa guru-guru selalu dilibatkan dalam rapat/musyawarah dalam pengambilan keputusan dalam pemecahan masalah yang ada, serta memberikan kesempatan pada guru untuk mengaplikasikan dan mengeluarkan potensipotensi yang mereka miliki. 
Edu Riligia : Vol. 4 No. 1 Januari- Maret 2020

\section{Kesimpulan}

Berdasarkan penelitian di lapangan didapatkan beberapa temuan bahwa: Perkembangan kemampuan profesionalisme guru di MTS Persiapan Negeri Hadundung Kecamatan Kota Pinang Kabupaten Labuhanbatu Selatan terbilang baik. Dapat diketahui secara keseluruhan guru yang mengajar di MTS Persiapan Negeri Hadundung Kecamatan Kota Pinang Kabupaten Labuhanbatu Selatan sudah memenuhi standart pendidikan. Rata-rata guru yang mengajar sudah memenuhi tingkat pendidikan sarjana/Strata Satu (S1). Ini dapat dilihat pada temuan umum pada bagian data guru bahwa jumlah guru yang tingkat pendidikannya sarjana (S1) ada 30 orang, dan guru yang tingkat pendidikannya masih diploma ada 1 orang. Apabila dikaitkan dengan kondisi pendidik yang dituntut pemerintah sekarang, sudah sesuai dengan apa yang diamanatkan Undang-Undang Republik Indonesia Nomor 14 Tahun 2005 tentang Guru dan Dosen, bahwa guru dan dosen harus sarjana atau diploma empat. Apabila dilihat dari bidang pendidikan guru hampir semua guru mengajar sesuai dengan keprofesionalan jurusan jenjang pendidikannya masing-masing (spesialisnya).

Kebijakan kepala sekolah terhadap peningkatan kemampuan profesionalisme guru di MTS Persiapan Negeri Hadundung Kecamatan Kota Pinang Kabupaten Labuhanbatu Selatan dari segi makro tergolong cukup baik. Ini dapat dilihat dari dokumen yang dibuat oleh guru berupa program tahunan, program semester, silabus dan RPP. Kebijakan makro yang lain yaitu kepala madrasah menganjurkan para guru untuk megikuti seminar pendidikan, pelatihan, dan penataran.

Kebijakan kepala madrasah dari segi mikro tergolong baik. Ini dapat dilihat dari kebijakan yang ditetapkan kepala madrasah yaitu: Menyarankan kepada guru untuk megikuti seminar pendidikan, mengadakan diskusi, musyawarah guru mata pelajaran (MGMP), rapat guru, studi kelompok antar 
Candra Wijaya, dkk: Strategi Manajemen Kepala Madrasah

guru, menggunakan laptop/media saat melakukan proses pembelajaran serta mengadakan evaluasi hasil belajar siswa pada pertengahan semester.

Berkenaan dengan keefektifan kebijakan kepala madrasah menurut peneliti sudah dapat dikatakan berhasil namun masih perlu di tingkatkan lagi kedepannya. Hal ini sesuai dengan penga matan peneliti waktu di lapangan bahwa guru-guru selalu dilibatkan dalam rapat/musyawarah dalam pengambilan keputusan dalam pemecahan masalah yang ada, serta memberikan kesempatan pada guru untuk mengaplikasikan dan mengeluarkan potensi-potensi yang mereka miliki.

\section{Endnote}

${ }^{1}$ Amiruddin, Administrasi Pendidikan, (Bandung: Cipta Pustaka, 2011), h. 5.

2 Syaiful Bahri Djamarah dan Aswan Zain, Strategi Belajar Mengajar, (Jakarta: Asdi Mahasatya, 2010) h. 5.

${ }^{3}$ Eti Rochaety, dkk., Sistem Informasi Manajemen, (Jakarta: Bumi Aksara, 2010), h.27.

4 Syafaruddin dan Asrul, Kepemimpinan Pendidikan Kontemporer, (Bandung: Citapustaka Media, 2015), h. 146

5 Yusuf Hadijaya, Menyusun Strategi Berbuah Kinerja Pendidik Efektif, (Medan: Perdana Publishing, 2013), h. 11.

h. 7

${ }^{6}$ Stephen P. Robbins dan Mary Coulter, Management,(New York: Prentice Hall, 2007),

${ }^{7}$ Richard Barret, Vocational Bussiness: Training, Developing and Motivating People, (t.t.: t.p., 2003), h. 51

${ }^{8}$ R. Griffin, Bussiness, (New York: Prentice Hall, 2007), h. 9.

${ }^{9}$ Rohiat, Manajemen Sekolah, (Bandung: Refika Aditama, 2009), h. 14.

${ }^{10}$ Mhd. Gade Ismail, Penelitian Kualitatif, (Banda Aceh: Syiah Kuala, 1993), h. 3. 
Edu Riligia : Vol. 4 No. 1 Januari- Maret 2020

\section{DAFTAR PUSTAKA}

Amiruddin. Administrasi Pendidikan. Bandung: Cipta Pustaka. 2011.

Barret, Richard.Vocational Bussiness: Training, Developing and Motivating People. t.th. t.p.

Djamarah, Syaiful Bahri dan Zain, Aswan. Strategi Belajar Mengajar. Jakarta: Asdi Mahasatya. 2010.

Griffin, R. Bussiness. New York: Prentice Hall. 2007.

Hadijaya, Yusuf. Menyusun Strategi Berbuah Kinerja Pendidike Efektif. Medan: Perdana Publishing. 2013.

Ismail, Mhd.Gade. Penelitian Kualitatif. Banda Aceh: Syiah Kuala. 1993.

Robbins, Stephen P. dan Coulter, Mary. Management. New York: Prentice Hall. 2007.

Rochaety, Eti, dkk. Sistem Informasi Manajemen. Jakarta: Bumi Aksara. 2010.

Rohiat. Manajemen Sekolah. Bandung:Refika Aditama. 2009.

Syafaruddin dan Asrul. Kepemimpinan Pendidikan Kontemporer. Bandung: Citapustaka Media. 2015. 